UDC 579.69

LBC 28.4

\title{
THE ANALYSIS PROTEOME DOMINANT SPECIES OF MICROORGANISMS IN AGROBIOCENOSIS THE VOLGOGRAD REGION FOR THE PRESENCE OF NICKEL AND COBALT-DEPENDENT PROTEINS ${ }^{1}$
}

\author{
Pavel A. Krylov \\ Volgograd State University, Volgograd, Russian Federation \\ Artem S. Isakov \\ Volgograd State University, Volgograd, Russian Federation \\ Elena N. Nesmeyanova \\ Volgograd State University, Volgograd, Russian Federation \\ Natalia A. Borozdina \\ Volgograd State University, Volgograd, Russian Federation \\ Margarita V. Postnova \\ Volgograd State University, Volgograd, Russian Federation \\ Valery V. Novochadov \\ Volgograd State University, Volgograd, Russian Federation
}

Abstract. The use of modern bioinformatic approaches for the solution of environmentally oriented tasks provides new data that can be used for spot control anthropogenic ecosystems and ecosystem rebuilding of their violation obtained from adverse factors of natural and antropogenical genesis. This work aims at demonstrating and identifying nickel and cobalt binding proteins in dominant species of microorganisms of agrocenosis that allows you to create an information database for accumulating and processing information about the regularities of the functioning of agro-ecosystem in arid conditions, leading to the growth of economic efficiency of the farming system and increase the success of environmental management. The main purpose of the work was to study the presence of nickel and cobalt binding proteins included in the proteome, the dominant species of microorganisms from three typical agrocenoses of the Volgograd region. Nickel and cobalt binding proteins were distributed not only in their functional features, participation in metabolism, proteolytic activity, transport and regulation of gene expression and proteins,

The results of virtual screening proteome the dominant microorganisms of the genus Bacillus and Actinomyces in the Uniprot database showed that the soil microbiota of the considered agrocenosis is also characterized by a sufficiently large number of metal - dependent proteins: 264 - for representatives of the Genus Actinomyces and 564 - for Bacillus subtilis, of of which about 35-40\% are annotated. According to the results, the concentration of metals in the soil of agrocenosis, namely in the arid zone, has a very strong impact on the livelihoods of crops and microorganisms in the soil. The use of the obtained results can be used as a basis for the implementation of targeted high-precision management of biocenoses in order to improve the sustainability of natural communities and the economic efficiency of agrocenoses.

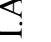
database.

Key words: agrocenoses, proteome, nickel, cobalt, metal binding proteins, agricultural nature management, 
УДК 579.69

ББК 28.4

\title{
АНАЛИЗ ПРОТЕОМА ДОМИНИРУЮЩИХ ВИДОВ МИКРООРГАНИЗМОВ В АГРОБИОЦЕНОЗАХ ВОЛГОГРАДСКОЙ ОБЛАСТИ НА НАЛИЧИЕ НИКЕЛЬ И КОБАЛЬТ ЗАВИСИМЫХ БЕЛКОВ ${ }^{1}$
}

\author{
Павел Андреевич Крылов \\ Волгоградский государственный университет, г. Волгоград, Российская Федерация
}

Артем Сергеевич Исаков

Волгоградский государственный университет, г. Волгоград, Российская Федерация

Елена Николаевна Несмеянова

Волгоградский государственный университет, г. Волгоград, Российская Федерация

Наталья Андреевна Бороздина

Волгоградский государственный университет, г. Волгоград, Российская Федерация

\section{Маргарита Викторовна Постнова}

Волгоградский государственный университет, г. Волгоград, Российская Федерация

\section{Валерий Валерьевич Новочадов}

Волгоградский государственный университет, г. Волгоград, Российская Федерация

Аннотация. Использование современных биоинформационных подходов для решения эколого-ориентированных задач обеспечивает получение новых данных, которые можно использовать для импактного управления агроценозами и экосистемами, восстанавливая их нарушения, обусловленные действием неблагоприятных факторов естественной и антропогенной среды. Данная работа направлена на выявление и определение никель и кобальт зависимых белков в доминирующих видах микроорганизмов агроценозе, что позволяет создать информационную базу для накопления и обработки сведений о закономерностях функционирования микроорганизмов в сельскохозяйственных системах аридной зоны, что будет способствовать повышению эффективности природопользования.

Основной целью работы являлось изучение наличия никель и кобальт зависимых белков, входящих в протеом доминирующих видов микроорганизмов типичных агроценозов Волгоградской области. Никель и кобальт зависимые белки были разделены по функциональным особенностям, таких как участие в метаболизме, гидролитической активности, транспорте и регуляции экспрессии генов и синтезе белков.

Результаты виртуального скрининга протеома доминирующих микроорганизмов рода Bacillus и Actinomyces в базе Uniprot, показали, что для почвенной микробиоты рассмотренного агроценоза также характерно достаточно большое количество металлзависимых белков: 264 - для представителей Рода Actinomyces и 564 - для Bacillus subtilis, из которых примерно 35-40 \% аннотированы. Полученные результаты свидетельствуют, что концентрация металлов в почве агроценоза является значимым фактором воздействия на жизнедеятельность микроорганизмов в почве. Полученные результаты можно использовать как основу для осуществления адресного высокоточного управления биоценозами с целью повышения устойчивости природных сообществ и экономической эффективности агроценозов.

Ключевые слова: агроценозы, протеом, никель, кобальт, металлзависимые белки, сельскохозяйственное природопользование, база данных.

Введение. В настоящее время наиболее актуальным подходом в развитии АПК является экологический системный подход к управ- лению агроценозами $[1,2,3]$. Использование и улучшение системного подхода может быть осуществлено за счет использования новых и 
перспективных биотехнологических решений. Например, комплексным управлением за счет внедрения в агроценоз новых ключевых игроков, таких как грибы и бактерии, относящиеся к биотическим факторам, так и возможным добавлением абиотических факторов, в частности, дополнительных элементов металлов никеля и кобальта, и других возможных климатических изменений $[3,4,6,8,10,12,13,14,15$, 17]. Особое место в динамике агробиоценозов занимают взаимодействия с прилегающими природно-антропогенными системами, которые при активном воздействии на искусственные биоценозы приобретают характер техногенных интрузий $[9,14]$. Для участков техногенных интрузий в агроценозы оптимально точечное управление $[4,6,16]$, что приводит к негативным изменениям агроценоза. Агроценозы этой территории характеризуются комплексом стрессовых факторов, оказывающих значительное влияние на перестройку метаболизма микроорганизмов и произрастающих растений, обитающих на этих территориях $[3,5,10,11]$. Bce это подтверждает необходимость изучения влияния металлов на молекулярном уровне на метаболизм микроорганизмов в агроценозе. Изучение никель и кобальт зависимых белков, входящих в протеом доминирующих представителей почвенной микробиоты, позволит выявить белки, участвующие в регулировании метаболизма. Полученные данные можно будет использовать для управления за счет регуляции метаболизма микроорганизмов влияющих на растения в агробиоценозе [7].

Цель работы - поиск и изучение никель и кобальт зависимых белков доминирующих видов представителей почвенной микробиоты агроценозов Волгоградской области.

Материалы и методы. Для изучения протеома и металлзависимых белков были отобраны доминирующие виды бактерий в трех агроценозах, территориально локализованных: Городищенский (аллея Ракутина) и Светлоярский (агрохозяйственая зона) муниципальные районы Волгоградской области и Советский район г. Волгограда (Горная поляна). Следующим этапом стало проведение биоинформационного анализа с использованием виртуального скрининга базы UniProt (www.uniprot.org). Скрининг осуществлялся по следующим критериям: наличие в составе белка никеля или кобальта и возникновение взаимодействия с данными металлами. Для поиска использовались синонимические конструкты следующего типа - cobalt AND organism: "Bacillus subtilis". Поиск производился по металлам, входящим в кофактор, а также по атомам - в металлсвязывающих сайтах. Таким образом, проводился отбор всех металлзависимых белков, которые содержат металл в своей структуре либо связываются с металлом для проявления своей активности. Структура базы знаний о металлзависимых белках строилась с помощью Microsoft Exel (США) У металлзависимых белков представителей микроорганизмов были выбраны основные функции: Гидролитическая активность, Регуляция экспрессии генов и синтеза белков дыхательная цепь, транспорт и метаболизм. Структура базы знаний может быть дополнена в случаи необходимости и решения других научно-исследовательских задач.

Результаты и их обсуждение. Произведен поиск металлазвисимых белков представителей доминирующих видов растений и микроорганизмов агробиоценозов Волгоградской области в UniProt. Поиск проводился по названиям организмов, металлы регистрировались в графах по Functions / Cofactors и Function / Sites / Metalbinding. Все белки, содержащие и связывающие металлы, были разделены по входящим в них металлам и выполняемым функциям.

Таблица 1

Металлзависимые белки, входящие в протеом доминирующих видов почвенной микробиоты в агроценозах Волгоградской области (по данным UniProt)

\begin{tabular}{|c|c|c|c|c|c|}
\hline \multirow{3}{*}{ Род/Вид } & \multicolumn{5}{|c|}{ Металлзависимые белки } \\
\hline & \multirow[t]{2}{*}{ Всего } & \multicolumn{2}{|c|}{$\begin{array}{c}\mathrm{C} \text { аннотированными } \\
\text { функциями }\end{array}$} & \multicolumn{2}{|c|}{$\begin{array}{c}\text { Без аннотированных } \\
\text { функций }\end{array}$} \\
\hline & & $\mathrm{Co}$ & $\mathrm{Ni}$ & $\mathrm{Co}$ & $\mathrm{Ni}$ \\
\hline Род Actinomyces & 264 & 0 & 101 & 49 & 114 \\
\hline Род Bacillus & 564 & 113 & 166 & 114 & 171 \\
\hline
\end{tabular}


В базе UniProt по роду Actinomyces, обнаружены 49 кобальтзависимых белков и 215 никельзависимых белков. У рода Actinomyces oтсутствуют аннотированные кобальтзависимые белки. Из 215 никельзависимых белков аннотировано меньше половины и составляет 101 белок. Среди кобальтзависимых белков преобладают белки, отвечающие за превращение веществ и функционирование ферментов, а также транспортной функции (табл. 2).

Стоит отметить, что на сегодняшний момент, очень мало описанных функциональных свойств кобальт- и никельзависимых белков, что не позволяет получить полные данные об их участие в регуляции других процессов жизнедеятельности представителей рода
Actinomyces в аридной зоне на территории агроценозов Волгоградской области

У представителей рода Bacillus subtilis функции никельзависимых белков в основном связаны метаболизмом и гидролитической активностью (табл. 3).

Найденные аннотированные никельзависимые белки отвечают за такие важные процессы как получение энергии - Bis(5'nucleosyl)-tetraphosphatase $\operatorname{PrpE}$ и Glycerol-1phosphate dehydrogenase $[\mathrm{NAD}(\mathrm{P})+]$, а также участии в образовании кофакторов для ферментов. Никель также является компонентом ферментов, осуществляющих гидролиз Putative metal-dependent hydrolase YfiТ и Hydrogenase maturation factor HypA.

Таблица 2

Описание кобальт-никель-зависимых белков, входящих в протеом Рода Actinomyces почвенной микробиоты агроценозов Волгоградской области

\begin{tabular}{|l|l|}
\hline \multicolumn{1}{|c|}{ Название белка } & \multicolumn{1}{|c|}{ Функция белка } \\
\cline { 2 - 2 } & \multicolumn{1}{|c|}{ Метаболизм } \\
\hline Allantoinase & $\begin{array}{l}\text { Катализирует превращение аллантоина (5-уреидогидантоина) в аллантоевую кисло- } \\
\text { ту путем гидролитического расщепления гидантоинового кольца с пятью звеньями }\end{array}$ \\
\hline $\begin{array}{l}\text { Urease accessory protein } \\
\text { UreG }\end{array}$ & $\begin{array}{l}\text { Облегчает функциональное включение никеля в металлоцентр уреазы. Этот процесс } \\
\text { требует гидролиза ГТФ, вероятно, осуществляемого UreG }\end{array}$ \\
\hline Nickel/cobalt efflux system & Транспорт \\
\hline
\end{tabular}

Таблица 3

Описание никельзависимых белков, входящих в протеом Bacillus subtilis почвенной микробиоты агроценозов Волгоградской области

\begin{tabular}{|c|c|}
\hline \multirow{2}{*}{ Название белка } & Функция белка \\
\hline & Метаболизм \\
\hline $\begin{array}{l}\text { Bis }(5 ' \text {-nucleosyl)- } \\
\text { tetraphosphatase PrpE }\end{array}$ & Гидролиз Ар4p для получения АМФ и АТФ \\
\hline Acireductone dioxygenase & $\begin{array}{l}\text { Катализирует } 2 \text { различных реакции между кислородом и ациредуктоновым 1,2-ди- } \\
\text { гидрокси-3-кето-5-метилтиопентином в зависимости от металла в активном участке }\end{array}$ \\
\hline $\begin{array}{l}\text { Glycerol-1-phosphate de- } \\
\text { hydrogenase [NAD }(\mathrm{P})+])\end{array}$ & $\begin{array}{l}\text { Катализирует NAD (P) H-зависимое восстановление дигидроксиацетонфосфата } \\
\text { (DHAP или глицеронфосфат) до глицерина 1-фосфата (G1P) и обратную реакцию }\end{array}$ \\
\hline Lactoylglutathione lyase & Катализирует превращение гемимеркаптала в S-лактоилглутатион \\
\hline \multirow[t]{2}{*}{$\begin{array}{l}\text { Pyridinium-3,5- } \\
\text { bisthiocarboxylic acid mo- } \\
\text { nonucleotide nickel inser- } \\
\text { tion protein }\end{array}$} & $\begin{array}{l}\text { Связывает } \mathrm{Ni}^{2+} \text { и выполняет его доставку в мононуклеотид пиридиний-3,5-бистиро- } \\
\text { карбо-новой кислоты для образования кофактора }\end{array}$ \\
\hline & Гидролитическая активность \\
\hline $\begin{array}{l}\text { Putative metal-dependent } \\
\text { hydrolase YfiT }\end{array}$ & Металлозависимая гидролаза \\
\hline $\begin{array}{l}\text { Urease accessory protein } \\
\text { UreG }\end{array}$ & $\begin{array}{l}\text { Способствует функциональному включению металлоценоза никелевого металло- } \\
\text { центра }\end{array}$ \\
\hline $\begin{array}{l}\text { Urease accessory protein } \\
\text { UreD }\end{array}$ & $\begin{array}{l}\text { Требуется для созревания уреазы посредством функционального включения метал- } \\
\text { лоцентра из никеля с уреазой }\end{array}$ \\
\hline $\begin{array}{l}\text { Urease accessory protein } \\
\text { UreE }\end{array}$ & $\begin{array}{l}\text { Сборка металлоцентров уреазы. Связывает никель. Функционирует как донор нике- } \\
\text { ля во время сборки металлоценоза }\end{array}$ \\
\hline $\begin{array}{l}\text { Hydrogenase maturation } \\
\text { factor HypA }\end{array}$ & $\begin{array}{l}\text { Созревание }[\mathrm{NiFe}] \text {-гидрогеназ. Требуется для введения никеля в металлический } \\
\text { центр гидрогеназы }\end{array}$ \\
\hline
\end{tabular}


Анализ протеома доминирующих видов микроорганизмов в агробиоценозах Волгоградской области

Найденные аннотированные никельзависимые белки отвечают за такие важные процессы как получение энергии - Bis(5'nucleosyl)-tetraphosphatase $\operatorname{PrpE}$ и Glycerol-1phosphate dehydrogenase $[\mathrm{NAD}(\mathrm{P})+]$, а также участии в образовании кофакторов для ферментов. Никель также является компонентом ферментов осуществляющих гидролиз Putative metal-dependent hydrolase YfiT и Hydrogenase maturation factor HypA.

Количество кобальт-зависимых белков у рода Bacillus subtilis примерно в 1.5 меньше чем никель-зависимых, но при этом обладают аналогичными функциями: гидролитическая активность и метаболизм, но при этом выполняют дополнительные функции, связанные с регуляцией экспрессией генов и белков H2HРP isomerase (табл. 4).

При сравнении кобальт- и никельзависимых белков между родом Bacillus subtilis и родом Actinomyces, видно, что никельзависимые белки в основном отвечают за метаболическую функцию, но у представителей рода
Bacillus subtilis данные белки не выполняют транспортных функций. Важно учитывать что еще около $50 \%$ белков рода Bacillus subtilis не аннотированы и преждевременно говорить о том, что они не выполняют в других функций. Также никельзависимые белки в основном обладают высокой гидролитической активностью, а вот кобальтзависимые в большей степени участвуют в метаболизме. При этом кобальтзависимые белки участвуют в регуляции экспрессии генов и белков.

Заключение. Таким образом, использование биоинформационных методов для изучения протеома позволило нам обнаружить кобальт- и никельзависимые белки и оценить их степень участия в процессах протекающих в микроорганизмах локализованных в аридной зоне на территории агроценозов Волгоградской области. Из полученных данных можно сказать, что наличие никеля и кобальта в почве может быть использовано как фактор для точеного управления развитием агроценоза. Это можно будет исполь-

Таблича 4

Описание кобальтзависимых белков, входящих в протеом Bacillus subtilis почвенной микробиоты агроценозов Волгоградской области

\begin{tabular}{|c|c|}
\hline Название белка & Функция белка \\
\hline \multicolumn{2}{|r|}{ Метаболизм } \\
\hline $\begin{array}{l}\text { Maltose-6'-phosphate glu- } \\
\text { cosidase }\end{array}$ & $\begin{array}{l}\text { Гидролиз maltose-6' -phosphate и trehalose-6'-phosphate. Участвует в катаболизме } \\
\text { альфа-гликозидов. Катализирует гидролиз 6-фосфо-альфа- и 6-фосфо-бета- } \\
\text { глюкозидов }\end{array}$ \\
\hline $\begin{array}{l}\text { Cadmium, zinc and cobalt- } \\
\text { transporting ATPase }\end{array}$ & $\begin{array}{l}\text { Гидролиз АТФ с переносом кадмия, цинка и кобальта из клетки. Не транспортирует } \\
\text { медь }\end{array}$ \\
\hline $\begin{array}{l}\text { Cadmium, cobalt and } \\
\text { zinc/H(+)-K(+) antiporter }\end{array}$ & $\begin{array}{l}\text { Гомеостаз калия в клетке. Катализирует активный отток цинка, кадмия и кобальта в } \\
\text { обмен на ионы калия и Н (+) }\end{array}$ \\
\hline $\begin{array}{l}\text { Cobalt-precorrin-5B } \\
\text { C(1)-methyltransferase }\end{array}$ & $\begin{array}{l}\text { Катализирует метилирование C-1 в cobalt-precorrin-5B с образованием Cobalt- } \\
\text { precorrin-6A }\end{array}$ \\
\hline Allantoinase & $\begin{array}{l}\text { Катализирует превращение аллантоина (5-уреидогидантоина) в аллантоевую кисло- } \\
\text { ту путем гидролитического расщепления гидантоинового кольца с пятью звеньями }\end{array}$ \\
\hline $\begin{array}{l}\text { Protein-arginine kinase ac- } \\
\text { tivator protein }\end{array}$ & Делокализация компетентных белков из полюсов клеток \\
\hline \multicolumn{2}{|r|}{ Гидролитическая активность } \\
\hline $\begin{array}{l}\text { Sirohydrochlorin } \\
\text { ferrochelatase }\end{array}$ & Хелат желза для предшественника сирогема \\
\hline $\begin{array}{l}\text { Uncharacterized } \\
\text { oxidoreductase } \mathrm{CzcO}\end{array}$ & $\begin{array}{l}\text { Катионный и двухвалентный катионный транспорт. Увеличивает транспортную ак- } \\
\text { тивность катионного транспортера калия CzcD }\end{array}$ \\
\hline Aminopeptidase AmpS & Металлозависимая экзопептидаза \\
\hline $\begin{array}{l}\text { Magnesium transport } \\
\text { protein CorA }\end{array}$ & Посредник притока ионов магния \\
\hline \multicolumn{2}{|r|}{ Регуляция экспрессии генов и синтеза белков } \\
\hline NAD kinase 1 & $\begin{array}{l}\text { Регуляция внутриклеточного баланса NAD и NADP, ключевой фермент в биосинте- } \\
\text { зе NADP. Катализирует специфическое фосфорилирование на 2'-гидроксильной } \\
\text { аденозиновой части NAD с получением NADP }\end{array}$ \\
\hline H2HPP isomerase & $\begin{array}{l}\text { Часть оперона bacABCDEF, ответственного за биосинтез не рибосомально синтезиро- } \\
\text { ванного дипептидного антибиотика bacilysin, состоящего из L-аланина и L-антапсина }\end{array}$ \\
\hline
\end{tabular}


зовать как основу для повышения устойчивости природных сообществ и экономической эффективности агроценозов.

\section{ПРИМЕЧАНИЕ}

1 Публикация подготовлена при финансовой поддержке Государственного задания Минобрнауки РФ по теме «Разработка экологоориентированных биотехнологий оптимизации аридных агробиоценозов Юга России на основе достижений физико-химической биологии и биоинформатики» (проект № 40.7534.2017/8.9).

\section{СПИСОК ЛИТЕРАТУРЫ}

1. Дудченко, Л.В. Эффективный биологический способ подавления сорных растений в полезащитных лесных насаждениях / Л. В. Дудченко // Достижения науки и техники АПК. - 2012. - № 7 . C. 37-38.

2. Зубков, А.Ф. Агробиоценологическая модернизация защиты растений / А. Ф. Зубков. - СПб. : ВИЗР, 2014. - 116 с. - (Приложение к журналу «Вестник защиты растений», № 12).

3. Мушаева, К.Б. Оценка современного состояния агропастбищных ландшафтов полупустынной зоны республики Калмыкия с применением ГИС-технологий / К.Б. Мушаева // Вестник Волгоградского государственного университета. Серия 11, Естественные науки. - 2015. - № 1. - С. 103-110.

4. Снижение негативного воздействия на агроценозы путем управления примыкающими природно-антропогенными системами / Е.А. Иванцова [и др.] // Вестник Волгоградского государственного университета. Серия 3: Экономика. Экология. 2017. - T. 19, № 4 (41). - C. 138-146. - DOI: 10.15688/ jvolsu3.2017.4.15.

5. Трифонова, Т.А. Моделирование стационарных состояний системы фитоценоз-почва (на примере бассейна р. Клязьма) / Т.А. Трифонова, Л.А. Ширкин, Н.В. Мищенко // Почвоведение. 2012. - № 8. - C. 889.

6. A functional trait perspective on plant invasion / R.E. Drenovsky [et al.] // Ann. Bot. - 2012. Vol. 110, № 1. - P. 141-153. - DOI: 10.1093/aob/mcs100.

7. Biochemical and molecular mechanisms of plant-microbe-metal interactions: relevance for phytoremediation / Y. Ma [et al.] // Front Plant Sci. 2016. - Vol. 7. - DOI: 10.3389/fpls.2016.00918

8. Biotic and abiotic drivers of intraspecific trait variation within plant populations of three herbaceous plant species along a latitudinal gradient / K. Helsen, [et al.] // BMC Ecol. -2017. - № 17. - P. 38.
9. Ecological aspects of phytosanitary optimization of arid agrobiocenoses of the south of Russia / E. A. Ivantsova [et al.] // Bulgarian J. Agric. Sci. - 2017. - Vol. 23, № 5. - P. 834-842.

10. In vitro antagonistic activity, plant growth promoting traits and phylogenetic affiliation of rhizobacteria associated with wild plants grown in arid soil /W. S. El-Sayed [et al.] // Front. Microbiol.-2014. - Vol. 5.

11. Influence of life form, taxonomy, climate, and soil properties on shoot and root concentrations of 11 elements in herbaceous plants in a temperate desert / M. He [et al.]// Plant and Soil. - 2016. - Vol. 398, № 102. - P. 339-350.

12. Invasive plants rapidly reshape soil properties in a grassland ecosystem / S. M. Gibbons [et al.] // mSystems. - 2017. - Vol. 2, № 2.

13. Leaf nitrogen and phosphorus of temperate desert plants in response to climate and soil nutrient availability / M. He [et al.] // Scientific Reports. - 2014. № 4. - P. 6932. - DOI: https://doi.org/10.1038/ srep06932.

14. Phylogenetic plant community structure along elevation is lineage specific / C. Ndiribe [et al.] // Ecology and Evolution. - 2013. - Vol. 3, № 15. P. 4925-4939.

15. Plant communities in harsh sites are less invaded: a summary of observations and proposed explanations / E. Zefferman [et al.] // AoBPlants. 2015. - № 7 .

16. Synergistic effects of the components of global change: Increased vegetation dynamics in open, forest-steppe grasslands driven by wildfires an d yearto-year precipitation differences / M. Kertesz, R. Aszalos, A. Lengyel, G. Onodi // PLoS One. -2017. Vol. 12, № 11 .

17. The database of the PREDICTS (Projecting Responses of Ecological Diversity In Changing Terrestrial Systems) project / L. N. Hudson [et al.] // Ecol. Evol. - 2017. - Vol. 7, № 1. - P. 145-188.

\section{REFERENCES}

1. Dudchenko L.V. Effectivniy biologicheskiy sposob podavleniya sornykh rasteniy $\mathrm{V}$ polezashchitnykh lesnyh nasazhdeniyahh [The Effective Biological Way of Suppressing the WeedPlants under Forest Belts]. Dostizheniya nauki i tekhniki APK [Achievements in Science and Technology of AIC], 2012, no. 7, pp. 37-38.

2. Zubkov A.F. Agrobiocenologicheskaya modernizatsiya zashchity rasteniy [Agrobiocenological Modernization of Plant Protection]. Saint Petersburg,VIZR Publ., 2014. 116 p.

3. Mushaeva K.B. Otsenka sovremennogo sostoyzniya agropastbishchnyh landshaftov 
polupustinnoy zony respubliki Kalmykiya s primeneniem GIS-tekhnologiy [Assessment of the Current State of Agropastoral Landscapes in Semi?Arid Areas of the Kalmykia Republic with Application of GIS-technologies]. Vestnik Volgogradskogo gosudarstvennogo universiteta. Seriya 11, Estestvennye nauki, 2015, no. 1, pp. 103-110.

4. Ivantsova E.A., Onistratenko N.V., Kholodenko A.V., Tikhonova A.A., Novochadov V.V. [Reduction of the Negative Impact on Agrocenoses by Managing Adjacent Natural and Anthropogenic Systems]. Vestnik Volgogradskogo gosudarstvennogo universiteta. Seriya 3, Ehkonomika. Ehkologiya, 2017, vol. 19, no. 4 (41), pp. 138-146. DOI: 10.15688/ jvolsu3.2017.4.15.

5. Trifonova T.A., Shirkin L.A., Mishchenko N.V. Modelirovanie statsionarnykh sostoyaniy sistemy fitotsentoz-pochva (na primereИсследование металлзависимых белков доминирующих видов растений и микроорганизмов Science Journal of VolSU. Global Economic System. 2018. Vol. 20. No. 4181 basseyna r. Klyazma) [Simulation of Stationary States of a Phytocenosis Soil System (the Case of the Klyazma River Basin]. Pochvovedenie [Pedology], 2012, no. 8, pp. 793-801.

6. Drenovsky R.E., Grewell B.J., D’Antonio C.M., Funk J.L., James J.J., Molinari N. et al. A functional trait perspective on plant invasion. Ann. Bot., 2012, vol. 110, no. 1, pp. 141-153.DOI: 10.1093/aob/mcs100.

7. Ma Y., Oliveira R.S., Freitas H., Zhang C. Biochemical and molecular mechanisms of plantmicrobe metal interactions: relevance for Phytoremediation. Front Plant Sci., 2016, no. 7. DOI: 10.3389/fpls.2016.00918

8. Helsen K., Acharya K.P., Brunet J., Cousins S.A.O., Decocq G., Hermy M., et al. Biotic and abiotic drivers of intraspecific trait variation within plant populgradient. BMC Ecol., 2017, no. 17 , p. 38 .

9. Ivantsova E.A., Onistratenko N.V., Kholodenko A.V., Tyutyuma N.V. Ecological aspects of phytosanitary optimization of arid agrobiocenoses of the south of Russia. Bulgarian J. Agric. Sci., 2017, vol. 23 , no. 5 , pp. 834-842.

10. El-Sayed W.S., Akhkha A., El-Naggar M.Y., Elbadry M. In vitro antagonistic activity, plant growth promoting traits and phylogenetic affiliation of rhizobacteria associated with wild plants grown in arid soil. Front. Microbiol., 2014, no. 5.

11. He M., Dijkstra F.A., Zhang K, Tan H., Yang Z., Li X. Influence of life form, taxonomy, climate, and soil properties on shoot and root concentrations of 11 elements in herbaceous plants in a temperate desert. Plant and Soil, 2016, vol. 398, no. 102, pp. 339-350.

12. Gibbons S.M., Lekberg Y., Mummey D.L., Sangwan N., Ramsey P.W, Gilbert J.A. Invasive plants rapidly reshape soil properties in a grassland ecosystem. mSystems, 2017, vol. 2, no. 2. DOI: 10.1128/ mSystems.00178-16.

13. He M., Dijkstra F.A., Zhang K., Li X., Tan H., Gao Y. et al. Leaf nitrogen and phosphorus of temperate desert plants in response to climate and soil nutrient availability. Scientific Reports, 2014, no. 4. DOI:https://doi.org/10.1038/srep06932.

14. Ndiribe C., Pellissier L., Antonelli S., Dubuis A., Pottier J., Vittoz P. et al. Phylogenetic plant community structure along elevation is lineage specific. Ecol. Evol, 2013, vol. 3, no. 15, pp. 4925-4939.

15. Zefferman E., Stevens J.T., Charles G.K., Dunbar-Irwin M., Emam T., Fick S., et al. Plant communities in harsh sites are less invaded: a summary of observations and proposed explanations. AoB. Plants, 2015, no. 7.

16. Kertesz M., Aszalos R., Lengyel A., Onodi G. Synergistic effects of the components of global change: Increased vegetation dynamics in open, forest-steppe grasslands driven by wildfires and yearto-year precipitation differences. PLoS One, 2017, vol. 12 , no. 11 .

17. Hudson L.N., Newbold T., Contu S., Hill S.L.L., Lysenko I., De Palma A., et al. The database of the PREDICTS (Projecting responses of ecological diversity in changing terrestrial systems) project. Ecol. Evol., 2017, vol. 7, no. 1, pp. 145-188.

\section{Information about the Authors}

Pavel A. Krylov, Candidate of Biology, Assistant, Department of Bioengineering and Bioinformatics, Volgograd State University, Prosp. Universitetskij, 100, 400062 Volgograd, Russian Federation, p.krylov.volsu@yandex.ru.

Artem S. Isakov, Student, Department of Bioengineering and Bioinformatics, Volgograd State University, Prosp. Universitetskij, 100, 400062 Volgograd, Russian Federation, isakov1996volg34@yandex.ru.

Elena N. Nesmeyanova, Student, Department of Bioengineering and Bioinformatics, Volgograd State University, Prosp. Universitetskij, 100, 400062 Volgograd, Russian Federation, nesmeyanovaelena97@yandex.ru. 
Natalia A. Borozdina, Student, Department of Bioengineering and Bioinformatics, Volgograd State University Prosp. Universitetskij, 100, 400062 Volgograd, Russian Federation, nataliaborozdina2016@yandex.ru.

Margarita V. Postnova, Doctor of Science (biology), Associate Professor, Head of Department of Bioengineering and Bioinformatics, Volgograd State University, Prosp. Universitetskij, 100, 400062 Volgograd, Russian Federation, postnova@volsu.ru.

Valery V. Novochadov, Doctor of Science (medicine) Professor, Director of the Institute of Natural Sciences, Volgograd State University, Prosp. Universitetskij, 100, 400062 Volgograd, Russian Federation, novovv@rambler.ru.

\section{Информация об авторах}

Павел Андреевич Крылов, кандидат биологических наук, ассистент кафедры биоинженерии и биоинформатики, Волгоградский государственный университет, просп. Университетский, 100400062 г. Волгоград, Российская Федерация, p.krylov.volsu@yandex.ru.

Артем Сергеевич Исаков, студент кафедры биоинженерии и биоинформатики, Волгоградский государственный университет, просп. Университетский, 100400062 г. Волгоград, Российская Федерация, isakov1996volg34@yandex.ru.

Елена Николаевна Несмеянова, студент кафедры биоинженерии и биоинформатики, Волгоградский государственный университет, просп. Университетский, 100400062 г. Волгоград, Российская Федерация, nesmeyanovaelena97@yandex.ru.

Наталья Андреевна Бороздина, студент кафедры биоинженерии и биоинформатики, Волгоградский государственный университет, просп. Университетский, 100400062 г. Волгоград, Российская Федерация, natalia-borozdina2016@yandex.ru.

Маргарита Викторовна Постнова, доктор биологическихз наук, доцент, зав. кафедрой биоинженерии и биоинформатики, Волгоградский государственный университет, просп. Университетский, 100400062 г. Волгоград, Российская Федерация, postnova@volsu.ru.

Валерий Валерьевич Новочадов, доктор медицинских наук, профессор, директор института естественных наук, Волгоградский государственный университет, просп. Университетский, 100 400062 г. Волгоград, Российская Федерация, novovv@rambler.ru. 